\title{
Chromosome localisation of nucleolar organizer region in Rhodophiala bagnoldii (Herb.) Traub (Asparagales: Amaryllidaceae) determined by silver nitrate staining
}

\section{Localización cromosómica de la región organizadora nucleolar en Rhodophiala bagnoldii (Herb.) Traub (Asparagales: Amaryllidaceae) determinada por tinción con nitrato de plata}

\author{
Pedro Jara-Seguel ${ }^{1}$, Claudio Palma-Rojas ${ }^{2}{\text {,Javier } \text { Contreras }^{2} \text { \& Elisabeth von Brand }}^{3}$
}

${ }^{1}$ Escuela de Ciencias Ambientales, Facultad de Recursos Naturales, Universidad Católica de Temuco, Casilla 15-D, Temuco-

Chile.

${ }^{2}$ Departamento de Biología, Facultad de Ciencias, Universidad de La Serena, Casilla 599, La Serena-Chile.

${ }^{3}$ Departamento de Biología Marina, Facultad de Ciencias del Mar, Universidad Católica del Norte, Casilla 117, Coquimbo, Chile.

pjara@uct.cl

\begin{abstract}
RESUMEN
Estudios cariotípicos en Rhodophiala bagnoldii (Herb.) Traub $(2 \mathrm{n}=18)$ han descrito constricciones secundarias subteloméricas localizadas en el brazo largo del par cromosómico 7. En este trabajo, una señal Ag-NOR positiva fue observada en la constricción secundaria de ambos cromosomas homólogos. Nucléolos fusionados y no fusionados fueron también observados en núcleos interfásicos de células meristemáticas.
\end{abstract}

The study of nucleolar organizer regions (Ag-NORs) provides information on chromosomal distribution of active versus silent rRNA genes due to the presence of acidic/argyrophilic domains in the RNA polymerase I transcription machinery (Schwarzacher et al. 1978, Medina et al. 1983, Cermeño et. al. 1984, Hubbell 1985, Carvalho et al. 2010), which is stainable by silver nitrate (Goodpasture \& Bloom 1975). The Ag-NOR technique has been complemented in the last years with the use of fluorescent in situ hybridization (FISH) using specific probes to indentify the physical localisation of ribosomal gene clusters (5S, 18S/25S) (Schwarzacher \& HeslopHarrison 2000). These methods, combined with the study of the number of nucleoli in interphase nuclei (FernándezGómez et al. 1969), have been a valuable tool to evaluate rDNA functionality in plant cells (Carvalho et al. 2010). However, the number of Chilean angiosperms for which the chromosome localisation of rDNA has been studied are little (ca. 19 species), and only two Amaryllidaceae species have been examined [e. g., Placea amoena Phil. and Rhodophiala aff. advena (Ker-Gawl.) Traub] (Baeza \& Schrader 2004, Baeza et al. 2006). Other two foreign species of the family have also been studied using Ag-NOR technique (e. g., Amaryllis belladona L. and Hippeastrum parodii Hunz. et Cocc.) (Naranjo \& Poggio 1988).

Rhodophiala is a South American genus represented by ca. 29 species. Karyotype studies in three Rhodophiala species from Chile ( $R$. aff. advena, $R$. bagnoldii and $R$. phycelloides; $2 \mathrm{n}=18$ ) coincide in that the secondary constrictions located in chromosome pair 7 may carry NOR (Palma-Rojas 2000). This description has been corroborated in $R$. aff. advena using FISH method (Baeza et al. 2006). However, nothing has been described for other Rhodophiala species whose karyotypes have been previously reported.

In this work the Ag-NOR technique was performed to locate active rDNA in chromosomes of $R$. bagnoldii. This species is endemic to Chile and inhabits from $23^{\circ}$ to $30^{\circ} \mathrm{S}$, being an important component of the flora of the Atacama dessert.

Plants and fruits of $R$. bagnoldii were collected in the Región de Coquimbo, Provincia de Elqui, Lagunillas locality, altitude $110 \mathrm{~m}\left(30^{\circ} 08^{\prime} \mathrm{S}-71^{\circ} 21^{\prime} \mathrm{W}\right), 28-\mathrm{X}-2008$, C. Palma s.n. (ULS). Root of germinated seeds from ten mother plants were pre-treated with colchicine $0.05 \%(\mathrm{w} / \mathrm{v})$ at $4^{\circ} \mathrm{C}$ for 3 hours, fixed in ethanol-glacial acetic acid $(3: 1 \mathrm{v} / \mathrm{v})$ at $4^{\circ} \mathrm{C}$ for 24 hours and stored in ethanol $70 \%(\mathrm{v} / \mathrm{v})$ at $4^{\circ} \mathrm{C}$ until require. A part of fixed roots were stained with the Feulgen reaction. The remaining roots were washed with distilled water and treated with a solution of pectinase-cellulase (Fluka 2:1 w/w) at 7.5\% $\left(\mathrm{w} / \mathrm{v}\right.$ ) in solution $0.2 \mathrm{M}$ of citrate buffer $\mathrm{pH} 4.2$ at $37^{\circ} \mathrm{C}$ for $30 \mathrm{~min}$. Chromosome preparations were made by squashing the root tips in $50 \%$ glacial acetic acid. The procedure used to obtain Ag-NOR bands was based on a modification of the techniques described by Hizume et al. (1980), Sánchez-Rufas 
et al. (1982) and Mehra \& Brekrus (1985). In addtition, the count of nucleoli in interphase nuclei was made following the method described by Fernández-Gómez et al. (1969).

The results of silver nitrate staining performed in mitotic metaphases of $R$. bagnoldii showed a positive Ag-NOR signal in subtelomeric location on the long arm of both homologous of the chromosome pair 7 (five metaphases). This observation corroborates the presence of the NOR in the secondary constrictions previously described by Palma-Rojas (2000) for the species (Fig. $1 \mathrm{a}, \mathrm{c})$. A similar situation has been observed in $R$. aff. advena using FISH method (Baeza et al. 2006). On the other hand, the presence of two nucleoli in interphase nuclei of $R$. bagnoldii shows independent activity of both NORs observed in chromosome pair 7 (Fig. 1b). However, nucleolar fusion was also observed with the presence of one large nucleoli in some meristematic cells. This nucleolar dynamics among fused and unfused nucleoli has been broadly described in plants and animals having different ploidy levels (Gosh 1976, Jordan et al. 1982). In this context, recent works have discussed this nucleolar dynamics and have revealed additional functions of the nucleoli in plants, where virtually all eukaryotic RNA polymerase-transcribed RNAs are processed and where other important cellular processes are regulated (Kim 2009, Carvalho et al. 2010).

The available data for Rhodophiala suggest that the subtelomeric localisation of the NOR in the long arm of the chromosome 7 is a conservative character within the karyotype of the genus and may be a robust marker to evaluate cytoevolutionary patterns (Palma-Rojas 2000, Baeza et al. 2006). Nevertheless, all these data should be interpreted with caution due to that only two species of the genus have been studied using specific techniques to study localisation and/or expression of ribosomal cistrons. In this sense, FISH method and/or silver nitrate staining are valuable tools to study NOR localisation and/or expression in plants such as those discussed by Carvalho et al. (2010).
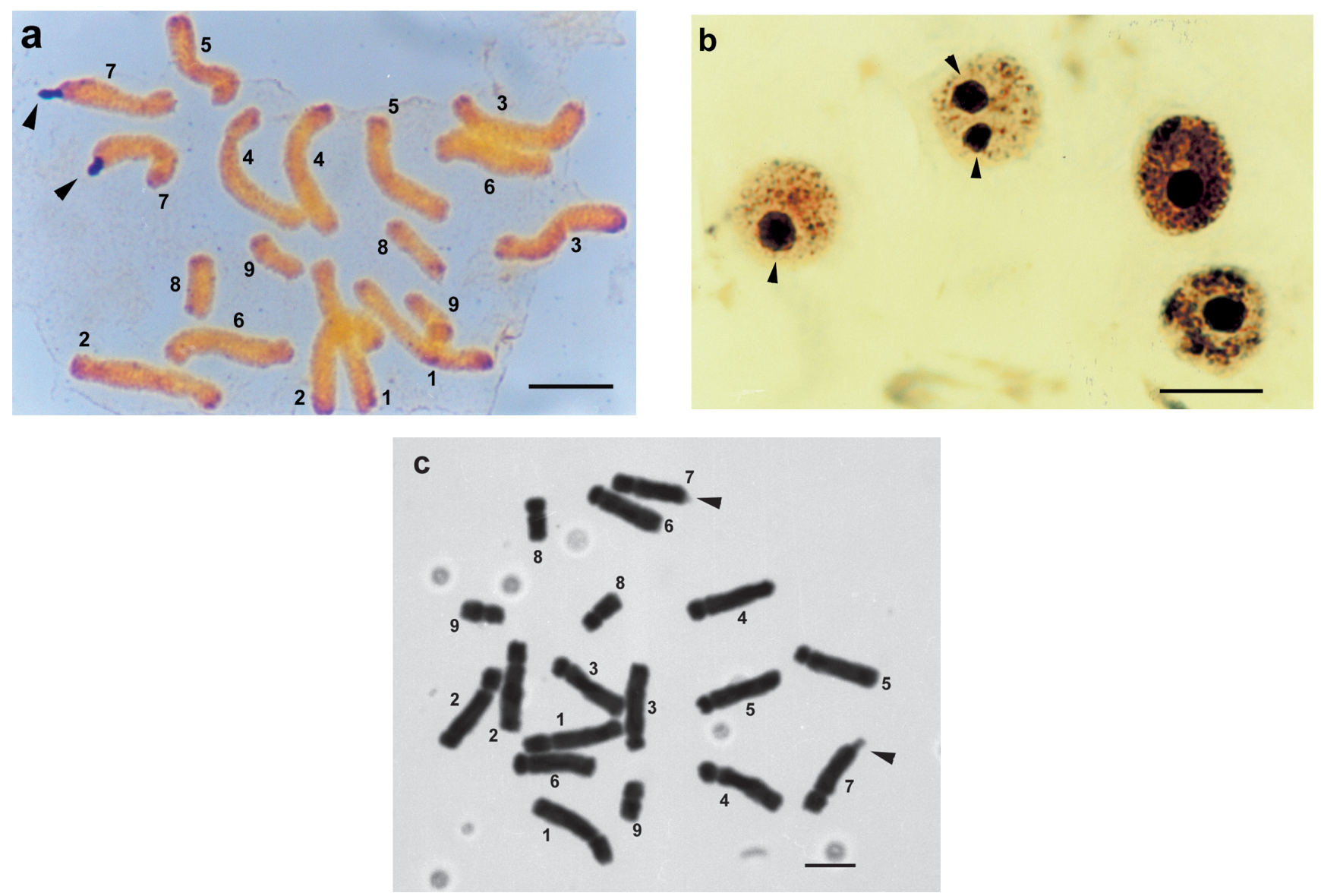

FIGURE 1. Rhodophiala bagnoldii $(2 \mathrm{n}=18)$. (a) Metaphase with Ag-NOR signals in subtelomeric localisation of the long arm of chromosome pair 7, (b) interphase nuclei with one and two nucleoli, and (c) Feulgen stained metaphase showing secondary constrictions in pair 7 (head arrows indicate Ag-NOR, nucleoli, and secondary constrictions, respectively). Bar $=10 \mu \mathrm{m}$.

Figura 1. Rhodophiala bagnoldii $(2 \mathrm{n}=18)$. (a) Metafase con señal Ag-NOR en localización subtelomérica en el brazo largo del par 7, (b) núcleos interfásicos con uno y dos nucléolos y (c) metafase teñida con Feulgen que muestra constricciones secundarias en el par 7 (puntas de flecha indican Ag-NOR, nucléolos y constricciones secundarias, respectivamente). Barra $=10 \mu \mathrm{m}$. 


\section{BIBLIOGRAPHY}

Baeza, M. \& O. Schrader. 2004. Karyotype analysis of Placea amoena Phil. (Amaryllidaceae) by double fluorescence in situ hybridization. Caryologia 57: 200-205.

Baeza, M., O. Schrader \& I. Escobar. 2006. Estudio del cariotipo de Rhodophiala aff. advena (Ker-Gawl.) Traub de la VIII Región de Chile. Kurtziana 32: 45-51.

Carvalho, A., C. Polanco \& J. Lima-Brito. 2010. Differential rDNA genes expression in hexaploid wheat related to NOR methylation. Plant Molecular Biology Reporter 28: 403-412.

Cermeño, M., J. Orellana, J. Santos \& J. Lacadena. 1984. Nucleorar organizer activity in wheat, rye and derivatives analized by a silver-staining procedure. Chromosoma 89 : 373-376.

Fernández-Gómez, E., J. Stockert, J. López-SÁez \& G. GiménezMartín. 1969. Staining plant cell nucleoli with $\mathrm{AgNO}_{3}$ after formalin-hydroquinone fixation. Stain Technology 44: 48-49.

Goodpasture, C. \& S. Bloom. 1975. Visualization of nucleolar organizer in mamalian chromosomes using silver staining. Chromosome 53: 37-50.

Gosh, S. 1976. The nucleolar structure. International Review of Cytology 57(1): 45-51.

Hizume, M., S. Sato \& A. TanaKa.1980. A highly reproducible method of nucleolus organizing regions staining in plants. Stain Technology 55(2): 87-90.

Hubbell, H. 1985. Silver staining as an indicator of active ribosomal genes. Stain Technology 60(5): 285-294.

Jordan, E., G. Martin, M. Bennett \& R. Flavel. 1982. Nucleolar fusion in wheat. Journal of Cell Science 56: 485-495.

KIM, S. 2009. Plant nucleolar dynamics. Journal of Plants Biology 52: 193-201.

Medina, F., M. Risueño, M. SÁnchez-Pina \& M. Fernández-Gómez. 1983. A study on nucleolar silver staining in plants cells. The role of argyrophilic proteins in nucleolar physiology. Chromosoma 88: 149-155.

Mehra, R. \& S. Brekrus. 1985. A simple two-step procedure for silver staining nucleolus organizer regions in plant chromosomes. Canadian Journal of Genetics and Cytology 22: 255-257.

Naranjo, C. \& L. Poggio. 1988. A comparison of karyotype, Ag-NOR bands and DNA content in Amaryllis and Hippeastrum (Amaryllidaceae). Kew Bulletin 43: 317325.

Palma-Rojas, C. 2000. Caracterización citogenética de los géneros Rhodophiala Presl. y Phycella Lindl. (Amaryllidaceae). En: P. Peñailillo \& F. Schiappacasse (eds.), Los geófitos nativos y su importancia en la floricultura: Fundación para la Innovación Agraria (FIA) y Dirección de Investigación, Universidad de Talca (DIUT), Santiago, Chile, pp. 73-79.

Sánchez-Rufas, J., P. Iturra, W. De Souza \& P. Sponda. 1982. Simple silver staining procedures for the location of nucleolous and nucleolar organizer under ligth and electron microscopy. Archives de Biologie 93: 267-274.

Schwarzacher, H., A. Mikelsaar \& W. Schnedl. 1978. The nature of the Ag-staining of nucleolus organizer regions. Cytogenetics and Cell Genetics 20: 24-39.

Schwarzacher, T. \& P. Heslop-Harrison. 2000. Practical in situ hybridization. BIOScientific, Oxford. 204 pp.

Recibido: 03.08.11

Aceptado: 05.12.11 